\title{
The Political Economy of Foreign Direct Investment to Developing Countries
}

\author{
Ms Nikki Harish \\ Dr Michael Plouffe* \\ School of Public Policy, University College London
}

2018.

* Corresponding author at michael.plouffe@ucl.ac.uk.

This paper was original prepared for the Handbook of the International Political Economy of Development, which as a whole, never appears to have made it to the submission stage. 


\section{What is FDI?}

Foreign direct investment, or FDI, is a form of international production, where productive assets in a host market are owned and controlled by residents of the home market (foreigners to the host market). In the IPE literature, it is frequently contrasted with foreign portfolio investment (FPI), which is less commonly studied. The distinction between the two rests on control over the investment. While both forms of foreign investment involve ownership, the use of FDI is controlled by the foreign owner. FDI is one option from a menu of methods through which firms can access foreign markets, and an essential component in global value chains or production networks. With the significant post-World War II growth in international production, FDI has emerged as a major feature of the global economy, raising the significance of a range of governance issues, both for national governments as well as international frameworks and organizations.

This chapter begins by describing FDI from an economic perspective, initially focusing on the characteristics and mechanics of FDI. It then addresses the actors actively involved in the FDI process and policies surrounding its governance at the domestic level, and its effects on a range of outcomes. Finally, we address global-governance issues.

\section{Types of FDI}

FDI is typically represented in two ideal-type forms in international political economy, based on the intent of the investment and the way it fits into the MNC's production network. Horizontal FDI is market-seeking in nature, essentially replicating the production line from the MNC's home country in the host market to produce identical (or nearly identical) products across both markets. A typical example of FDI of this type is Coca-Cola, which is produced by the Coca-Cola Company across a wide range of host markets, with a final product that does not vary significantly across markets. ${ }^{1}$ This is contrasted with vertical FDI, where the investment is focused on accessing raw materials or producing an intermediate input to the final product, fragmenting the MNC's supply chain across both home and host economies. Vertical FDI is an international approach to vertical integration, the domestic form of which has been studied extensively in economics, particularly with relation to the boundaries of the firm within a market (Coase, 1937; Williamson, 1973). Where horizontal FDI implies the replication of a supply chain across markets, vertical FDI can be viewed as the expansion of a single supply chain across international markets. The underlying motivations for each type of FDI differ significantly, lending themselves to tractable analytical approaches. However, in practice, production-focused FDI typically contains both elements of horizontal and vertical characteristics, leading to veri-zontal FDI.

\footnotetext{
1 The notable exception here is in Coca-Cola's home market, the United States, where sugar protection and corn subsidies mean that the final product is based on high-fructose corn syrup, rather than sugar. Consequently, there is demand in the home market for the host-market version of the product.
} 
Yet another form of FDI is relatively under-researched, despite frequent references from politicians and the general media: tax haven FDI. Tax haven FDI differs significantly from production-focused FDI in that its sole purpose for existence is to allow a MNC to take advantage of favourable tax policies by incorporating a subsidiary or affiliate and running business operations through that arm of the corporation. While many of the same determinants of production FDI factor into tax-haven FDI decisions (Haberly and Wojcik, 2015; Jones and Temouri, 2016), little existing political-economy research addresses tax haven FDI.

\section{Why Choose FDI for Production?}

FDI provides one way for firms to access foreign markets. Firms have a large menu of options for internationalization. The costs and benefits of these international activities are determined by a range of foreign market characteristics. While importing and exporting are less costly ways for firms to internationalise, ${ }^{2}$ FDI provides one way for MNCs to access markets insulated by high tariff or non-tariff barriers. The FDI decision itself can be easily explained through a series of economic models.

The differences between MNCs and firms solely investing domestically have long been a topic of study. ${ }^{3}$ John Dunning's organizing approach, known as the Ownership-Location-Internalization (OLI) framework, emerged as perhaps the most ubiquitous approach to explaining the necessary market conditions for FDI. ${ }^{4}$ Dunning sought to identify conditions that made direct investment an attractive option in the face of higher costs associated with such a method of entering foreign markets.

Table 1 - Components of Dunning's OLI Framework

\begin{tabular}{|l|l|}
\hline Principle Component & Description \\
\hline Ownership Advantage & $\begin{array}{l}\text { This describes products or an aspect (such as a patent, trade secret, trademark, } \\
\text { reputation, etc.) of the production process controlled by the MNC that other firms } \\
\text { do not possess. }\end{array}$ \\
\hline Location Advantage & $\begin{array}{l}\text { The foreign market must have some characteristic that makes it attractive, while } \\
\text { precluding exports as a viable alternative to FDI. These features may be inherent } \\
\text { to the market, such as cheap factor prices or a large domestic market, or could be } \\
\text { based on trade costs. }\end{array}$ \\
\hline Internalisation Advantage & $\begin{array}{l}\text { There needs to be an advantage to internal foreign production; otherwise, licensing } \\
\text { production to a foreign partner or exporting domestically produced products are } \\
\text { more attractive alternatives. }\end{array}$ \\
\hline
\end{tabular}

The OLI framework consists of three components, as described in Table 1. One of these - the locational advantage - refers to market features, while the others, ownership and internalisation, identify characteristics of the firm. Where these factors all coincide, FDI is a profitable enterprise.

\footnotetext{
${ }^{2}$ Both are still costly at the firm level. Bernard et al. 2007 provide an excellent overview of the economic aspects of this. Plouffe 2015 discusses the implications for the political economy of trade.

${ }^{3}$ Hymer 1976; Kindleberger 1969 are early examples.

${ }^{4}$ Dunning 1977, 1981.
} 
Ownership advantages typically arise from knowledge-based (intangible) assets. Knowledge capital possesses different attributes from physical capital (including specific assets), making FDI are more likely outcome: knowledge capital can be easily transferred geographically, and it can easily be shared across multiple facilities without reducing facility-specific productivity. Consequently, firms that rely heavily on knowledge-capital assets are well positioned to directly invest both domestically and internationally, allowing the firm to achieve economies of scale. Consequently, ownership advantages are associated with sources of firm heterogeneity and market power, potentially leading to significant deviations from perfect competition.

Locational advantages depict economic incentives for MNCs to enter foreign markets. Without these, firms would focus on domestic markets at the expense of expansion abroad. Locational advantages vary widely in the ways in which they incentivise foreign expansion. They may involve access to natural resource deposits - one of the key drivers for FDI flows prior to the latter half of the $20^{\text {th }}$ century. ${ }^{5}$ Locational advantages may also result from access to cheap factors of production; large quantities of unskilled labour are an essential attraction for FDI flows following Heckscher-Ohlin patterns. Finally, domestic market size is a locational advantage, especially where trade barriers are substantial, reducing the incentive to export.

Locational advantages are not necessarily constricted to the potential host market. MNCs may choose to invest in a market because of the access it provides to a larger regionally integrated market. ${ }^{6}$ This is particularly common where free trade areas (FTAs) link several markets, with rules of origin (ROO) limiting the benefits of the FTA to those goods at least partially produced within the bloc. FDI in this case provides an MNC with a way to reduce trade or production costs through vertical integration of production within the FTA. FDI in this instance may be efficiency oriented, as MNCs take advantage of efficiency gains to be found within the trade bloc; it may also take the form of export platform FDI, where the MNC's investment allows it to expand its reach horizontally into the trade bloc. This leads to a growth in FDI to countries with cheaper factors of production or lower tax rates than their trade-bloc counterparts. For example, following the ratification of NAFTA, Mexico experienced a surge in FDI from American manufacturers seeking to reduce labour costs. ${ }^{7}$ In the case of the European common market, a number of small countries, like Ireland, have become attractive hosts for export-platform FDI as MNCs exploit favourable tax rates. ${ }^{8}$

Some locational advantages may be temporary in nature, as potential host governments seek to attract FDI through policy measures aimed at reducing barriers to investment or providing additional non-market incentives to invest. For many developing countries, the 1980s saw the implementation of institutional reforms that dramatically reduced barriers to foreign investment

\footnotetext{
${ }^{5}$ Frieden 1991 and 2007 provide useful analyses of the political economy of these flows.

${ }^{6}$ Chase 2003; Manger 2009.

${ }^{7}$ Cite Gordon Hanson.

${ }^{8}$ Navaretti and Venables 2008, chapter 8?
} 
and led to a significant increase in FDI flows to reforming countries. ${ }^{9}$ Many governments provide temporary inducements to MNCs to attract FDI, from direct or indirect subsidies, preferential tax policies, promises of infrastructure, and grants and subsidized loans. ${ }^{10}$ These practices are fairly common, with more than two-thirds of African countries using tax holidays to attract investment, ${ }^{11}$ and subsidies a fairly common practice among developed-country governments. In fact, competition at the sub-national level to attract FDI often leads to rival packages of incentives for potential investors, which has become a standard approach to attracting with foreign automotive investment in the American South. ${ }^{12}$

Internalisation advantages simply dictate whether these activities occur within the boundaries of the firm or outside these boundaries. Advantages of this nature may arise from both intangible and specific assets. The value of intangible assets may be tied to the MNC itself, and thus eroded if licensed to a third party; or it may reduce the extent to which the MNC can rely on product differentiation to drive its sales. In the case of specific assets, licensing or outsourcing production to an unrelated producer may provide a solution to access a foreign market, but the nature of these assets generates significant contracting issues that create strong internalisation advantages. Specific assets are skills or equipment that are specially tailored to a single purpose; this requires specialised investment, and under incomplete contracting, can lead to the hold-up problem. The solution to this is simply keeping the production processes requiring specific assets internal to the MNC.

\section{Revisiting Incentives to Invest Abroad}

While the OLI framework fits nicely with theories of the firm, one of its shortcomings lies in its eclectic nature. It predates modern approaches to industrial organisation, and the firm-specific factors that give rise to ownership and internalisation advantages present a greater context for the decision-making process surrounding FDI and related forms of accessing foreign markets. Target market characteristics are handily confined to locational advantages, although market imperfections arising from incomplete contracting and features intrinsic to the production process are divided between ownership and internalisation.

Table 2, below, presents a breakdown of the sources of market failures that lead to FDI. The types of assets involved in the MNC's production process then dictate the ways in which the investment fits into the corporation's production network. Where intangible assets drive FDI, it will be focused on accessing the host market; where specific assets are the key driver, the investment will be focused on cost reduction or resource/material access. As illustrated, locational advantages

\footnotetext{
${ }^{9}$ See Bonnichta et al. 2017, chapter 1. Frieden 2007 describes the development context behind the creation of many of these barriers.

10 Brewer and Young 1997; Cleeve 2008.

${ }^{11}$ Cleeve 2008.

12 Neven and Siotis 1993; Jensen, Malesky, Medina and Ozdemir 2013.
} 
must be present in the host market for FDI to occur; without incentives to access foreign markets, firms will maintain production domestically.

Table 2 - Explaining Integration and FDI

\begin{tabular}{|c|c|c|c|}
\hline \multirow{4}{*}{ 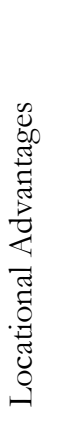 } & \multicolumn{3}{|c|}{ Market Imperfections } \\
\hline & & Intangible Assets & Specific Assets \\
\hline & Yes & Horizontally Integrated MNC & Vertically Integrated MNC \\
\hline & No & Horizontally Integrated Domestic Firm & Vertically Integrated Domestic Firm \\
\hline
\end{tabular}

\section{Heterogeneous Producers and Market Access}

FDI is only a viable option for the most productive firms; while the economic activities of MNCs dominate the global economy, MNCs make up a small percentage of the overall population of firms. Firms, both within and across industries, vary significantly in both size and productivity; ${ }^{13}$ which lead to differences in market behaviours. Ownership and internalisation advantages arise from this producer heterogeneity as well, as aspects of heterogeneity have been linked to variations in managerial practices and intellectual property. ${ }^{14}$

Market entry is determined by fixed (and sunk) entrance and variable continuation costs. ${ }^{15}$ Of all the different options for accessing foreign markets, FDI has the highest fixed costs of entry. Consequently, while market conditions may appear to benefit FDI, not all potential MNCs can afford to invest. While most firms that engage in international markets focus on a single product and a single market, those that deal in multiple products and/or markets tend to use a diverse set of methods to do so. Consequently, a MNC may engage in FDI to enter some markets, while using trade as a means of accessing others. ${ }^{16}$ Where this FDI is horizontal in nature, it acts as a substitute for intra-firm trade, while vertical FDI complements such trade.

\section{The Actors and Domestic Effects of FDI}

From an IPE perspective, a wide range of actors are involved in the politics of developing-country FDI. Among the most obvious from an economic perspective are MNCs themselves and their domestic counterparts. The highly productive nature of MNCs can spell difficulty for competing

\footnotetext{
13 Most research focuses on total factor productivity differences - or variations in the efficiency with which firms combine all of their inputs - but this is also true for labour productivity or capital productivity.

${ }^{14}$ See, for example, Antra and Helpman 2008 and Marin and Verdier 2008.

${ }^{15}$ Helpman 2006 and Bernard et al. 2007 provide introductory surveys to the related economics.

16 Plouffe 2017 discusses this for Japanese manufacturers.
} 
domestic host-country producers. However, the impact of FDI on domestic producers varies by the type of investment, the sector receiving investment, and the extent to which knowledge spillovers are encouraged. ${ }^{17}$

Inbound FDI can be expected to be a politically important issue for host governments. MNCs can exert a significant amount of lobbying pressure on host governments that frequently desire to attract FDI for its contributions to economic growth. These incentives to attract FDI may be countered by opposition from domestic producers, as well as domestic sources of public opposition. Public opposition to FDI typically encompasses concerns over issues frequently linked to foreign investment, while producer sentiments are often driven by competition concerns. Both forms of expression are subject to domestic rules regulating representation.

\section{Time Inconsistency and the Obsolescing Bargain}

The argument behind the political determinants of FDI rests in the obsolescing bargain between the MNC and host government. Potential host-country governments face a time inconsistency problem relating to the governance of foreign investments. ${ }^{18}$ Prior to the concrete decision on investment location, an MNC holds greater power than potential host governments, all of which have incentives to compete with each other to attract FDI, offering incentives such as promises of tax holidays, subsidies, or infrastructure investments, among other inducements. Once the direct investment is made, it is extremely costly for the MNC to withdraw, causing power within the relationship to shift to the host government. ${ }^{19}$ Host governments thus face a timeinconsistency problem, with incentives to attract new FDI flows turning into incentives to opportunistically extract revenue from existing FDI stocks. As the composition of FDI flows has changed over time, so too has the nature of the obsolescing bargain.

Through the 1970s, the obsolescing bargain most frequently manifested itself in the nationalization, or direct expropriation, of MNCs' assets. ${ }^{20}$ These assets were heavily concentrated in primary extractive industries targeting high value commodities, such as oil and gold. Time and again, once the domestic workforce gained sufficient experience in operating the MNCs' equipment, the opportunity to increase the portion of revenues kept in the host country became irresistible for many host governments.

Direct expropriation has lasting negative effects on a country's ability to attract future FDI inflows, and the frequency of these actions has waned significantly since the $1980 \mathrm{~s}^{21}$ This decline can be attributed to several causes: greater appreciation of direct expropriation's negative influence on future FDI flows by host governments; the shifting composition of FDI flows away from

\footnotetext{
17 Markusen and Venables 1999.

${ }^{18}$ Frieden 1991; Henisz 2000; Stasavage 2002.

${ }_{19}$ Vernon 1971 provides the classic exposition.

${ }^{20}$ Frieden 1991, 2007.

${ }^{21}$ Akhtaruzzaman et al. 2017.
} 
extractive investments; and the diffusion of bilateral investment agreements (discussed at the end of this chapter).

Following the failure of Import Substitution Industrialization (ISI) and the Debt Crisis of the $1980 \mathrm{~s},{ }^{22}$ developing countries were encouraged to adopt a more liberal and open stance toward the global economy. ${ }^{23}$ An indirect consequence of this involved pressure against direct expropriation of FDI; however, by this point, most easily nationalized investments had already been expropriated. ${ }^{24}$ The composition of FDI flows to developing countries shifted away from extractive FDI towards manufacturing and services, reducing potential gains from direct expropriation. These non-extractive investments tend to be much more highly integrated with an MNC's regional or global production network, linking their value more directly to the ties within this network. If directly expropriated, the investment's production network-driven value is lost. This value could stem from a range of sources, such as intellectual property that is inseparable from the MNC (such as the earlier Coca Cola example) or input/output production that is inextricably connected to other components of the MNC's production network. MNC production networks involving arm's-length trade benefit from the effects of partner firms possessing incentives to protect property rights of the other members within the network. ${ }^{25}$

Rather than eliminate an investment's value through direct expropriation, an opportunistic host government may engage in partial expropriation - deviating from established policies to increase its portion of revenues extracted from the MNC's assets. While less costly to the MNC than complete nationalization of its investment, the costs of partial expropriation may render its activities within the host country unprofitable. Regulations that impose partial expropriation or restrictions on international capital transfers have largely replaced direct expropriation. While veto players are linked to reduced partial expropriation, they have no effect on government decisions to impose transfer restrictions. ${ }^{26}$

Various domestic institutional arrangements can make such political risk unlikely, while investment agreements may allow the MNC to claim compensation on its lost revenues. While expropriation activities harm the MNC and its shareholders and leads to reduced future FDI inflows, expropriating governments may benefit on sovereign debt markets, highlighting divergent preferences over property rights among different classes of investors. ${ }^{27}$

\section{Domestic Institutions and the Political Determinants of FDI}

\footnotetext{
22 Taylor 1998 discusses this in greater detail.

23 Williamson 1993, 2000.

${ }^{24}$ Frieden 2007.

25 Johns and Wellhausen 2016.

${ }^{26}$ Graham et al. 2017.

${ }^{27}$ Wellhausen 2015.
} 
An extensive literature assesses the impact of domestic political institutions on FDI, with a particular focus on developing countries. MNCs are risk averse when identifying potential locations for their foreign investments, as direct investment is highly illiquid. Domestic institutional quality is consequently of primary concern to MNCs, as these define the local regulatory environments in which they operate their investments. ${ }^{28}$ The market for assessing political risk and insuring against its mal-effects is quite large, although many MNCs forgo the costly opportunity to insure their investments against sources of political risk. These risks arise from a range of institutional features, from regime turnover or corruption, to a lack of rule of law or outright armed conflict. Property rights and access to due process (or the broad application of rule of law) ultimately are the most widespread political determinants of FDI. ${ }^{29}$

A distinction also exists between host-country governments. Democracies are more likely to attract FDI than autocracies, as their institutions tend to do more to enshrine the qualities MNCs seek, ${ }^{30}$ and they are more likely to pursue liberal investment policies. ${ }^{31}$ Democracies additionally tend to provide more veto points than autocracies, thus ensuring greater policy stability, reducing the potential for policy makers to behave opportunistically with respect to the investment and its outputs. However, some investors prioritize market access and quick negotiations over political risk, as in the case of agricultural investments. ${ }^{32}$ Likewise, the substantial institutional and legal variations among autocracies contribute to heterogeneous veto-player impacts, with consequent disparities in the governance of foreign investment. ${ }^{33}$ Finally, here the investment decision is facilitated through relationships, such as within migrant networks, rather than formal legal contracts, political-institution quality matters less in the investment decision, highlighting similar heterogeneity among investors when it comes to political-risk sensitivity. ${ }^{34}$

However, while the effects of these political determinants are often highly statistically significant, their substantive effects on investment are quite limited, and they provide little predictive value. ${ }^{35}$ Rather than focusing on the political environments of potential host countries, MNC decision makers rely on a host country's economic characteristics, such as market access or the existence of location-specific resources.

Flipping this relationship on its head, FDI has also been linked to domestic reform of political institutions. For example, the distribution FDI stocks is linked to increased decentralization of political power to subnational leaders. ${ }^{36} \mathrm{FDI}$ inflows are also linked to higher levels of corruption,

\footnotetext{
${ }^{28}$ Busse and Hefeker 2001.

${ }^{29}$ Jensen 2003, 2006. Li and Resnick 2003.

30 Jensen 2008; Li 2009.

31 Pandya 2014.

32 Bastiens 2016.

33 Jensen et al. 2013.

${ }_{34}$ Graham 2014; Pandya and Leblang 2017.

35 Arel-Bundock 2017.

36 Malesky 2008.
} 
as greater market concentration reduces the difficulty with which officials can extract rents from firms. ${ }^{37}$

\section{Economic Consequences of FDI: Inequality and Diffusion Effects}

Despite substantial literature addressing globalisation as a positive route to economic growth and integration, Rudra emphasises that globalisation continues to disadvantage the poorest in society, continuing the effects of domestic institutions which she argues ignore the welfare of the poor. ${ }^{38}$ The positive impact of investment on economic growth is well established; however, FDI's relationship with economic growth - as well as development - is more complicated. The impact of FDI on economic growth has been extensively studied, particularly as developing countries have sought to harness its potential to spur growth following the establishment of the Washington Consensus. The evidence of FDI's impact on growth is mixed. At the macroeconomic level, there are heterogeneous effects, which appear to be mediated by financial development. ${ }^{39}$ However, analyses of FDI flows aggregated at the level of the country-year mask considerable variation in the nature and impact of FDI projects. At the microeconomic level, there are similar theoretical expectations: FDI generates productivity improvements through reallocations of market share and resources as the least productive operating domestic firms are forced to exit production. ${ }^{40}$ Few studies attempt to isolate the productivity effects of FDI, but these would be expected to have a positive impact on growth. ${ }^{41}$

Both vertical and horizontal FDI can lead to the direct and indirect spillover of foreign expertise by enabling workers within the developing countries to be exposed to foreign skills enabling them to improve human capital in the developing country. ${ }^{42}$ These spillovers may be horizontal coming from foreign enterprises within the same industry - or vertical - stemming from foreignowned producers of inputs used by domestic firms. Many studies find that MNCs contribute to higher levels of pay, introduce new technologies, and retain larger capital and skills. ${ }^{43}$ Increases in human capital can improve productivity, encouraging economic growth within the host country. ${ }^{44}$ Foreign firms tend to provide higher wages, use more technologies and train their staff more, leading to higher expertise for workers within foreign firms. The presence of foreign competition can lead to the diffusion of technology and knowledge, stimulating domestic firms to improve their technologies which thus increases their productivity. ${ }^{45}$ The impact of FDI on domestic economic settings often derives from larger sizes of foreign firms and their tendency to provide

\footnotetext{
${ }^{37}$ Pinto and Zhu 2016.

38 Rudra 2008.

39 See, for example: Borenzstein et al. 1998; Nair-Reichert and Weinhold 2001; Alfaro et al. 2004.

${ }^{40}$ Helpman et al. 2004; Yeaple 2007 (theories of firm heterogeneity).

41 Alfaro and Chen 2014; Alfaro 2016.

${ }^{42}$ Carkovic and Levine 2002.

43 Dunning 1993; Caves 1996; Carkovic and Levine 2002.

${ }^{44}$ Balasubramanayam et al. 1996; Krueger and Lindahl 2001.

45 Blomström and Sjöholm 1999; te Velde 2003.
} 
more training compared to domestic firms. ${ }^{46}$ However, the positive effects of competition can be limited depending on the capacity of domestic firms to compete. The efficiency and increasing market power of MNCs can drive out inefficient domestic companies, due to their potential market dominance as the result of technological expertise. ${ }^{47}$ Such market-share reallocation is anticipated in formal economic models, with the least productive domestic firms exiting the market as a result of entry by highly productive foreign MNCs. ${ }^{48}$

MNCs have strong incentives to limit spillovers and the diffusion of technology and knowledge, while host governments seek to promote these effects, placing the two in a potentially adversarial situation. These incentives for MNCs align with the internalization aspect of FDI; even when anj investment involves a domestic partner, efforts are made to limit spread of proprietary knowledge. Furthermore, the actual spillover or diffusion effect of FDI could be limited by the capacity of domestic producers to absorb any technological expertise or knowledge capital that is shared by the investing MNC. There often exists are large gap in knowledge levels within the host country with respect to those required within MNCs; this can serve to limit or even eliminate altogether the influence of positive spillover effects, reducing the abilities of local firms to improve their own productivities as a result of FDI inflows. ${ }^{49}$ Particularly where existing training and education policies are inadequate, this exacerbates the negative implications of FDI. The effect of FDI therefore is largely contingent upon policies within the domestic country: positive influences on the domestic economy are stunted in the absence of supportive policies. In practice, there is little or no evidence of spillovers from horizontal FDI, ${ }^{50}$ this contrasts with vertical investments, where positive productivity spillovers have been encountered both upstream and downstream along the supply chain. ${ }^{51}$ These vertical-integration induced spillovers are likely to be encouraged by the $\mathrm{MNC}$ as a way of ensuring consistent quality control and input supply. ${ }^{52}$

FDI's effects on other political-economy outcomes are of similar importance. FDI to developing countries has been strongly linked to increased levels of income and wage inequality in the host country through increased returns to human capital and education. ${ }^{53}$ One reason for this lies in the fact that FDI tends to provide more advantages to skilled workers in comparison to unskilled workers in emerging economies. While FDI that takes advantage of differing factor endowments along the lines of the Heckscher-Ohlin model would be expected to reduce inequality through increased employment of low-skilled workers in developing economies, this logic does not necessarily extend to empirical reality. Rather, in the case of FDI from developed economies, hostcountry employment may be biased in favour of relatively inexpensive semi-skilled or highly-skilled

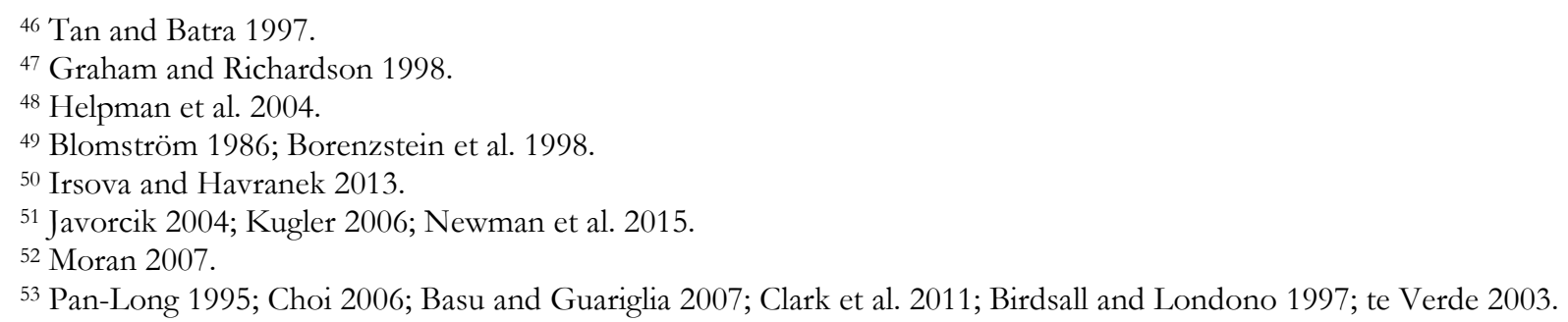


workers, weakening any potential relationship to reduced inequality. In fact, evidence tends to demonstrate the opposite effect: FDI increases income inequality, effectively leaving the least skilled workers behind. This is particularly the case with South-South FDI, which tends to not be driven by Heckscher-Ohlin factors.

While FDI can increase productivity through the introduction of new technologies, these often induce skill-biased technological change (find another similar source) ${ }^{54}$ Moreover, since MNCs are typically reliant upon skilled workers, individuals with the required skills, education and knowledge are usually limited in number and reside in an advantageous position as they can bargain for higher wages (reference). The sectoral allocation of FDI also influences inequality: where FDI targets skill-intensive sectors, inequality increases, as low-skilled workers are unlikely to directly. Further exacerbating the wage gap is the fact that MNCs are typically responsible for increased worker training and education when compared to domestic firms, increasing the potential earnings gap between skilled and unskilled workers.

\section{FDI's Non-market Externalities}

In addition to its widely documented economic effects, FDI has been linked to substantial consequences for host countries outside the concerns of traditional economic analyses. As with other aspects of globalization - in particular, international trade - FDI has long been associated with a regulatory 'race to the bottom', in which developing countries compete to reduce regulatory burdens on foreign MNCs in an effort to attract investment. Any reductions to existing regulations then have the potential to adversely impact the host country's population and resources. However, evidence of the race to the bottom and its effects remains mixed.

In addition to the influence of regulatory interactions with FDI, effective governance structures are essential for promoting positive externalities from investments. ${ }^{55}$ However, in bids to attract FDI, host governments will often overlook these effects. ${ }^{56}$

\section{FDI, Tax Policy, and the Welfare State}

Governments often propose tax-based incentives as a means of attracting foreign investment. In the developed world, there are well-known cases of subnational governments competing against each other to attract FDI, such as competition between states in the American South to attract automotive investment. In general, such tax incentives on their own primarily attract mobile capital, which is more responsive to changes in the marginal tax rate. ${ }^{57}$ Fixed investments are more

\footnotetext{
${ }^{54}$ Berman and Machin 2000.

55 Reiter and Steensma 2010.

${ }_{56}$ Benmamoun and Lehnert 2013; Lehnert et al. 2013.

${ }^{57}$ de Mooij and Ederveen 2008.
} 
likely to be drawn by other aspects of the investment environment, such as regulatory and infrastructure quality. ${ }^{58}$

The budget constraint on a government's ability to offer tax incentives to foreign MNCs is more restrictive in the developing world than among developed countries. It also potentially brings about more significant negative fiscal effects for the domestic population, as many developing-country welfare states provide a minimal safety net. ${ }^{59}$ While significant variation in welfare-state size does exis, there is no clear welfare-state link between FDI and inequality, as the poorest members of developing-country societies have often historically been excluded when it has come to welfare policies, and any tax-driven benefit reductions more strongly affect the middle classes. ${ }^{60}$ There is also evidence that developing-country governments attempt to offset globalization's redistributive effects through public employment, although these measures are often targeted to politically important groups. ${ }^{61}$

\section{FDI and Labour Standards}

With respect to labour standards, host governments have incentives to competitively reduce regulatory requirements in an effort to attract FDI seeking access to relatively cheap factors of production. However, labour costs are just one factor in the broader decision over both choice of market-access mechanism and investment location if FDI is the preferred method. Some evidence has pointed to the existence of a race-to-the-bottom effect here (Jenkins, 1999), as MNCs utilize FDI to more effectively compete on price. As a result, workers see increased hours, reduced pay, and diminished working conditions.

In recent decades, corporate social responsibility has emerged as an increasingly important component in the production sourcing process. From consumers seeking out ethically-sourced goods from fair-trade coffee to labour-friendly sportswear (Hiscox 2006?), firms have incentives to be able to demonstrate a commitment to ethical treatment of labour. Rodrik (1996) finds that countries with higher labour standards attract more FDI, as they often mirror the ethical standards of developed countries; however, this may also reflect differences in the determinants of FDI between richer and poorer countries (Blonigen and Wei, 2005).

However, there is evidence of a 'climb-to-the-top' effect of FDI on labour, with FDI to developing countries associated with greater collective labour rights (Mosley and Uno, 2007). Domestic enforcement of statutory labour rights is essential to ensure that MNCs - as well as domestic employers - respect labour regulations in practice, rather than violating human and labour rights (OECD, 2008). More recently, Cho (year) has argued that labour standards have limited influence

\footnotetext{
58 James 2013.

${ }^{59}$ Rudra 2002, 2007.

${ }^{60}$ Rudra and Haggard 2005; Rudra 2008.

${ }^{61}$ Nooruddin and Rudra 2014.
} 
on the choice of FDI location. More important in the FDI location decision are the market and political environment.

MNCs often differ from each other in the skill composition of their hiring patterns in host countries, with these skill requirements differing significantly by industry (Yeaple, 2003). Industry (or investment)-based divergences in skill composition are likely to influence the interaction between FDI and labour standards in the host country, although no studies to date successfully tease this relationship out. Similarly, MNCs often differ from domestic producers in the gender breakdown of their host-country workforces. While Anker and Hein (1985) find that female workers are often less likely to strike than their male counterparts, they are often paid far less. MNC entry through FDI often reduces the gender pay gap, increasing female workforce entry (Kabeer, 2000; Sarna, YEAR). MNCs themselves can benefit from exploiting a wide host-country gender wage gap by taking advantage of the reduced cost of female employment. However, these gender-gap improvements are likely to be short-lived; as Braunstein (2005) notes that female workers are particularly susceptible to employment volatility.

\section{Environmental Impacts of FDI}

The relationship between FDI and environmental regulations, like that of labour standards, is dominated by debate around the race-to-the-bottom argument. ${ }^{62}$ Ultimately, the effects of FDI on host countries' natural environments are mixed. The sector within which FDI is located has a significant influence on its impact on the environment: for example, FDI targeting resource extraction often has a large and direct negative environmental effect, while service-sector FDI is much less likely to have an immediate influence on environmental quality. The functional use of FDI varies significantly across sectors, driving the observed heterogeneous sector-based environmental impacts.

The quality of host-country institutions also influences the impact of FDI on the environment, through two mechanisms, both of which also impact the treatment of environmental resources by domestic producers. The first of these is the quality of existing regulatory institutions. Pollution and other forms of environmental degradation will be reduced where these governing bodies can both effectively set and enforce permissible levels of destruction. Implementation of these policies is more difficult when regulators can be convinced to disregard statutes and their enforcement. The second mechanism is the democratic process: if members of the public can effectively pressure their government with demands for more effective environmental governance, the government will respond by improving environmental standards and their enforcement.

In another parallel to labour standards, consumer preferences can contribute to substantial changes in MNC supply-chain management practices. In the absence of strong host-country environmental standards, MNCs targeting ethical consumers or wishing to demonstrate a commitment to

62 See, for example, Wheeler 2001; Prakash and Potoski 2006. 
corporate social responsibility may sign on to internationally-recognized private regulatory standards. ${ }^{63}$ For example, MNC adoption of ISO 14001 environmental standards to certify their outbound FDI to developing countries is driven by home country ISO 14001 adoption. ${ }^{64}$ These private standards may exceed host-country environmental regulations and even contribute to improvements in these regulations. ${ }^{65}$

\section{The Investment Treaty Regime and Development}

We have discussed efforts by host-country governments to govern FDI and its effects within their borders. The cross-national nature of FDI flows and the extent of their embeddedness within MNC production networks creates governance issues that similarly span international borders. Increasingly these risks have been dealt with through the investment-treaty regime, which includes over three thousand investment protection treaties and the arbitral tribunals through which claims are disputed. ${ }^{66}$ Most investment protection treaties are bilateral in nature (leading to a considerable academic literature on BITs, or bilateral investment treaties), and investment protection clauses are also increasingly found as components of broader economic-integration agreements, like the North American Free Trade Agreement (NAFTA), the Energy Charter Treaty (ECT), or the more recent Comprehensive Economic and Trade Agreement (CETA), Trans-Pacific Partnership (TPP), and Regional Comprehensive Economic Partnership (RCEP). Most investment treaties are North-South agreements, where the developing country expected the treaties to result in more inward foreign investment. ${ }^{67}$ These investment-attraction efforts may be driven by the need to increase the public-revenue base in the event of increasing debt-servicing costs. ${ }^{68}$ Yet, developing countries have also signed a large number of treaties among themselves, with little reasonable expectation of greater investment flowing as a result. ${ }^{69}$

\section{Investment treaty arbitration}

The most notable feature of the investment treaty regime is its dispute-settlement process. Here, foreign investors are given permission to file international arbitration claims against their host state governments. Although arbitral rules vary, investment treaty arbitration usually include three party appointed arbitrators determining the disputes and awarding financial damages for treaty breaches. Notably, the arbitration process does not require investors to exhaust local remedies, thereby allowing them to avoid the domestic legal system prior to filing a claim. Only investors can file claims; states cannot file claims against investors. More than 700 investment treaty claims have

\footnotetext{
63 Prakash, 2002; Potoski and Prakash, 2005a.

${ }^{64}$ Potoski and Prakash, 2005b; Prakash and Potoski, 2007.

65 Prakash and Potoski, 2007.

${ }^{66}$ Bonnitcha et al. 2017.

${ }^{67}$ Elkins et al., 2006; Poulsen 2015.

${ }^{68}$ Betz and Kerner 2015.

${ }^{69}$ Jandhyala, Henisz, and Mansfield.
} 
been brought to date, most in recent years. Although claims are increasingly being brought against developed countries, most claims have been brought against developing countries.

The claims have touched upon a very wide range of government measures and often resulted in very significant financial damages. ${ }^{70}$ For developing countries, in particular, the high legal fees involved often also constitute a concern. More broadly, developing country governments have often been taken by surprise by the 'bite' of the treaties in practise. ${ }^{71}$

\section{Economic impact}

Investment treaties can be a useful last resort for investors confronted with obsolescing bargain and opportunistic host government behaviours. BITs, the predominant form of investment treaties, often cover a range of investment types, not limiting themselves to FDI; however, their application to FDI is of particular importance because of its high sunk costs - particularly for investments in natural resources and infrastructure. The costs of the arbitration process mean that the treaties are primarily, though not exclusively, relevant for disputes involving large investors and investments.

One direct implication of the very broad definition of investment is that the range of investors who file claims under BITs usually ranges from direct and controlling investors to non-controlling and indirect stockholders. ${ }^{72}$ Additionally, investors may be natural persons or legal persons; in the latter case, BITs may vary in their handling of the corporation's home country, linking it to the location of legal incorporation, while some treaties impose headquarters or significant business operations as additional considerations.

These considerations can influence corporate structuring and the routing of investments to ensure they are covered by an active BIT. For example, Mobil Corporation, which is incorporated in the United States, restructured a Venezuelan investment through a Dutch subsidiary after the investment had been made in order to obtain protection under the Netherlands-Venezuela BIT, as there is no investment treaty between the United States and Venezuela. ${ }^{73}$ In the case where a MNC's home country and its investment host have a BIT, an investment made through a foreign subsidiary located in a third-party country without an investment agreement with the host country could also still be subject to the BIT between the home and host country as a result of the MNC's indirect ownership of the investment.

The combination of potent substantive protections, wide coverage of investments and investors, and independent recourse to international arbitration has made investment treaties critical instruments for the resolution of certain investment disputes. For developing countries, however,

\footnotetext{
70 Zoe Williams xx.

71 Aisbett and Poulsen 2013, Poulsen 2014, 2015.

72 Bonnitcha et al. 2017.

${ }^{73}$ Mobil v Venezuela, Decision on Jurisdiction.
} 
the core question is whether this power of the treaties translate into economic benefits. In particular, do foreign firms rely on the treaties when deciding where, and how much, to invest? Survey evidence suggest that few investors factor in the treaties in the establishment phase, but the literature is largely divided and often hampered by the poor quality of FDI data. ${ }^{74}$ This has resulted in concerns that developing countries may have signed up to potent property right protections with few, if any, economic benefits in return.

A related question is whether the treaties are more effective in strong host institutional environments or weak host institutional environments. ${ }^{75}$ Some studies find that the treaties 'substitute' for poor institutional environments and can promote the rule of law, but other scholars warn that giving foreign investors the option of side-stepping domestic courts it may reduce pressure for prudent judicial reforms. ${ }^{76}$ These are understudied, but important, questions to understand the developmental impact of the treaties. Finally, empirical scholarship has begun to assess the extent to which investment treaty arbitration may assist developing countries in 'depoliticizing' investment disputes - by removing the home state from the equation - but here again existing results have been disappointing. ${ }^{77}$

The combination of significant political and economic costs associated with investment treaty arbitration and questionable economic and political benefits has made some developing countries rethink their support for the investment treaty regime. For example, while Latin American countries were particularly prolific in their adoption of BITs in the 1980s and 1990s, the tide has since turned, to the extent that Bolivia, Ecuador, and Venezuela have all ended some BIT agreements and withdrawn from the ICSID Convention. ${ }^{78}$ But also outside of Latin America, negotiators have begun to address various concerns about the arbitration process and potential for politicization of investment arbitration.

\section{A Look Forward}

Research on the political economy of FDI, particularly in IPE, has progressed significantly in its theoretical and methodological rigor, enabling greater understanding of the causes and effects of cross-national direct investment flows. Despite this, much remains unknown, either as a result of contradictory or inconclusive results or simply a lack of empirical study. Some issues arise from the highly aggregated nature of key constructs, while other concerns relate to the actual measurement of core phenomena of FDI itself..$^{79}$ And while political concerns, in particular FDI's

\footnotetext{
74 Yackee 2009; Cotula et al. 2016; Bonnitcha et al. 2017.

75 Neumayer and Spess 2005; Tobin and Rose-Ackerman 2011.

${ }^{76}$ Ginsburg xx.

77 Gertz, Jandhyala, and Poulsen 2018.

78 Waibel et al., 2010; Bonnitcha et al., 2017.

${ }^{79}$ Bonnitcha et al., 2017 discuss the former. Kerner, 2014 discusses the latter.
} 
political determinants, remain an important part of the story, they appear to have little predictive power when it comes to determining where FDI flows. ${ }^{80}$

It is important to remember that FDI is but a single component in the menu of internationalization choices available to globally engaged firms, particularly MNCs. ${ }^{81}$ While most international political economy research continues to focus on a single aspect of internationalization - trade, offshoring, FDI, etc. - these activities play different roles within production networks, and the extent to which they complement each other or act as substitutes, and the influence of political factors on these effects, remains an active focus of research. ${ }^{82}$

Finally, questions remain concerning the future direction of the international treaty regime. While the regime itself has undergone little change with regard to its underlying norms and practices, the international environment surrounding investment governance has evolved. Between the incorporation of ISDS into broader economic integration efforts and growing popular backlash against the one-sided nature of obligations and potential sovereignty impingements of that mechanism, there is potential that the future investment treaty regime differs significantly from the one in place today.

\footnotetext{
80 Arel-Bundock, 2017.

${ }^{81}$ Pandya 2016; Plouffe 2017.

${ }^{82}$ Jensen et al. 2015 provides an example of research linking value-chain participation to other aspects of policy.
} 


\section{References}

Akhtaruzzaman, M., Nathan Berg, and Christopher Hajzler. 2017. Expropriation risk and FDI in developing countries: Does return of capital dominate return on capital?. European Journal of Political Economy.

Alfaro, Laura. 2016. 'Gains from Foreign Direct Investment: Macro and Micro Approaches.' World Bank Economic Review: 1-14.

Alfaro, L., Chanda, A., Kalemli-Ozcan, S., \& Sayek, S. 2004. 'FDI and economic growth: the role of local financial markets.' Journal of International Economics, 64(1): 89-112.

Alfaro, Laura, and Maggie Xiaoyang Chen. 2014. 'The Global Agglomeration of Multinational Firms.' Journal of International Economics, 94(2): 263-276.

Anker, R. and Hein, C., 1985. Why Third World urban employers usually prefer men. International Labour Review, 124, p.73.

Antras, Pol and Elhanan Helpman. 2008. 'Contractual Frictions and Global Sourcing.' In Helpman et al. eds. The Organization of Firms in a Global Economy. Cambridge: Harvard University Press.

Arel-Bundock, Vincent. 2017. The political determinants of foreign direct investment: A firm-level analysis. International Interactions, 43(3): 424-452.

Basu, P., and A. Guariglia. 2007. 'Foreign direct investment, inequality, and growth.' Journal of Macroeconomics, 29(4): 824-839.

Benmamoun, Mamoun and Kevin Lehnert. 2013. Financing growth: comparing the effects of FDI, ODA, and international remittances. Journal of Economic Development, 38(2): 43.

Bernard, Andrew B, J Bradford Jensen, Stephen J Redding, Peter K Schott. 2007. 'Firms in International Trade.' Journal of Economic Perspectives.

Betz, Timm and Andrew Kerner. 2015. 'The influence of interest: Real US interest rates and bilateral investment treaties.' Review of International Organizations, 11(4):419-448.

Borensztein, E., De Gregorio, J., \& Lee, J. W. 1998. 'How does foreign direct investment affect economic growth?’ Journal of International Economics, 45(1): 115-135.

Busse, M. and C. Hefeker. 2007. Political risk, institutions and foreign direct investment. European Journal of Political Economy, 23(2), pp.397-415.

Choi, C. 2006. 'Does foreign direct investment affect domestic income inequality?' Applied Economics Letters, 13(12), 811-814. 
De Mooij, Ruud A. and Sjef Ederveen. 2008. 'Corporate tax elasticities: A reader's guide to empirical findings.' Oxford Review of Economic Policy, 24(4): 680-697.

Clark, D. P., Highfill, J., de Oliveira Campino, J., \& Rehman, S. S. 2011. 'FDI, technology spillovers, growth, and income inequality: A selective survey.' Global Economy Journal, 11(2).

Coase, Ronald H. 1937. The nature of the firm. Economica, 4(16): 386-405.

Cotula, Lorenzo, Giedre Jokubauskaite, Pierre-Etienne Kenfack, Moustapha Ngaido, Samuel Nguiffo, Téodyl Nkuintchua, and Eric Yeboah. 2016. 'Land investments, accountability and the law: Lessons from West Africa.' International Institute for Environment and Development.

Dunning, John H. 1977. 'Trade, Location of Economic Activity and MNE: A Search for an Eclectic Approach.' In Ohlin, B, PO Hesselborn, and PM Wijkman, eds. The International Allocation of Economic Activity. London: Macmillan, 395-418.

Dunning, John H. 1981. International Production and the Multinational Enterprise. London: George Allen and Unwin.

Frieden, Jeffry A. 1991. Invested interests: The politics of national economic policies in a world of global finance. International Organization, 45(4): 425-451.

Frieden, Jeffry A. 2007. Global capitalism: Its fall and rise in the twentieth century. WW Norton \& Company.

Gertz, G., S. Jandhyala, and L. N. S. Poulsen. 2018. 'Legalization and Diplomacy: Evidence from the investment regime.' Working paper.

Graham, Benjamin A.T. 2014. 'Diaspora-owned firms and social responsibility.' Review of International Political Economy, 21(2): 432-466.

Graham, Benjamin A.T., Noel P. Johnston, and Allison F. Kingsley. 2017. 'Even constrained governments take: The domestic politics of transfer and expropriation risks.' Journal of Conflict Resolution, forthcoming.

Haberly, Daniel and Dariusz Wójcik. 2014. Tax havens and the production of offshore FDI: an empirical analysis. Journal of Economic Geography, 15(1): 75-101.

Hymer, Stephen H. 1976. The International Operations of National Firms: A Study of Direct Foreign Investment. Cambridge: MIT Press.

James, Sebastian. 2013. 'Tax and non-tax incentives and investments: Evidence and policy implications.' Investment Climate Advisory Services of the World Bank Group. 
Jandhyala, Srividya, Witold J. Henisz, and Edward D. Mansfield. 2011. 'Three waves of BITs: The global diffusion of foreign investment policy.' Journal of Conflict Resolution 55, 1047-1073.

Jensen, J. Bradford, Dennis P. Quinn, and Stephen Weymouth. 2015. 'The influence of firm global supply chains and foreign currency undervaluations on US trade disputes.' International Organization, 69(4): 913-947.

Johns, Leslie and Rachel L. Wellhausen. 2016. 'Under one roof: Supply chains and the protection of foreign investment.' American Political Science Review, 110(1): 31.

Jones, Chris and Yama Temouri. 2016. The determinants of tax haven FDI. Journal of World Business, 51(2): 237-250.

Kerner, Andrew. 2014. 'What we talk about when we talk about foreign direct investment.' International Studies Quarterly, 58(4), 804-815.

Kindleberger, Charles P. 1969. American Business Abroad. New Haven: Yale University Press.

Lehnert, Kevin, Mamoun Benmamoun, and Hongxin Zhao. 2013. FDI Inflow and Human Development: Analysis of FDI's Impact on Host Countries' Social Welfare and Infrastructure. Thunderbird International Business Review, 55(3): 285-298.

Li, Quan. 2009. Democracy, autocracy, and expropriation of foreign direct investment. Comparative Political Studies, 42(8): 1098-1127.

Malesky, Edmund J. 2008. 'Straight ahead on red: How foreign direct investment empowers subnational leaders.' Journal of Politics, 70(1): 97-119.

Marin, Dalia and Thierry Verdier. 2008. 'Competing in Organizations: Firm Heterogeneity and International Trade.' In Helpman et al. eds. The Organization of Firms in a Global Economy. Cambridge: Harvard University Press.

Mosley, Layna and Saika Uno. 2007. Racing to the bottom or climbing to the top? Economic globalization and collective labor rights. Comparative Political Studies, 40(8): 923-948.

Nair-Reichert, U., \& Weinhold, D. 2001. 'Causality Tests for Cross-Country Panels: A New Look at FDI and Economic Growth in Developing Countries.' Oxford Bulletin of Economics and Statistics, 63(2), 153-171.

Nooruddin, Irfan and Nita Rudra. 2014. Are developing countries really defying the embedded liberalism compact?. World Politics, 66(4), pp.603-640.

OECD. 2008. 'The Social Impact of Foreign Direct Investment.' https://www.oecd.org/els/emp/The-Social-Impact-of-foreign-direct-investment.pdf 
Pan-Long, T. 1995. 'Foreign direct investment and income inequality: further evidence.' World Development, 23(3): 469-483.

Pandya, Sonal S. 2014. 'Democratization and foreign direct investment liberalization, 1970-2000.' International Studies Quarterly, 58(3): 475-488.

Pandya, Sonal S. 2016. 'Political economy of foreign direct investment: Globalized production in the twenty-first century.' Annual Review of Political Science 19: 455-475.

Pandya, Sonal and David Leblang. 2017. 'Risky business: Institutions vs. social networks in FDI.' Economics and Politics, forthcoming.

Pinto, Pablo M. and Boliang Zhu. 2016. 'Fortune or evil? The effect of inward foreign direct investment on corruption.' International Studies Quarterly, 60(4): 693-705.

Plouffe, Michael. 2015. 'Heterogeneous Firms and Policy Preferences.' In Lisa Martin, ed. The Oxford Handbook of the Political Economy of International Trade. Oxford: Oxford University Press. 196-212.

Plouffe, Michael. 2017. 'Firm Heterogeneity and Trade-Policy Stances: Evidence from a Survey of Japanese Producers.' Business and Politics 19(1): 1-40.

Potoski, Matthew and Aseem Prakash. 2005a. Green clubs and voluntary governance: ISO 14001 and firms' regulatory compliance. American Journal of Political Science, 49(2), pp.235-248.

Potoski, Matthew and Aseem Prakash. 2005. Covenants with weak swords: ISO 14001 and facilities' environmental performance. Journal of Policy Analysis and Management, 24(4), pp.745769.

Poulsen, Lauge N Skovgaard. 2014. Bounded rationality and the diffusion of modern investment treaties. International Studies Quarterly, 58(1): 1-14.

Poulsen, Lauge N Skovgaard and Emma Aisbett. 2013. When the claim hits: Bilateral investment treaties and bounded rational learning. World Politics, 65(2): 273-313.

Prakash, Aseem. 2002. Green marketing, public policy and managerial strategies. Business Strategy and the Environment, 11(5): 285-297.

Prakash, Aseem and Matthew Potoski. 2006. Racing to the bottom? Trade, environmental governance, and ISO 14001. American Journal of Political Science, 50(2): 350-364.

Prakash, Aseem and Matthew Potoski. 2007. Investing up: FDI and the cross-country diffusion of ISO 14001 management systems. International Studies Quarterly, 51(3): 723-744. 
Reiter, Sandy L. and H. Kevin Steensma. 2010. Human development and foreign direct investment in developing countries: the influence of FDI policy and corruption. World Development, 38(12), pp.1678-1691.

Rudra, Nita. 2002. Globalization and the decline of the welfare state in less-developed countries. International Organization, 56(2), pp.411-445.

Rudra, Nita. 2007. Welfare states in developing countries: unique or universal?. Journal of Politics, 69(2), pp.378-396.

Rudra, N., 2008. Globalization and the Race to the Bottom in Developing Countries. Cambridge: Cambridge Books.

Rudra, Nita and Stephan Haggard. 2005. Globalization, democracy, and effective welfare spending in the developing world. Comparative Political Studies, 38(9), pp.1015-1049.

Taylor, Alan M. 1998. On the costs of inward-looking development: price distortions, growth, and divergence in Latin America. Journal of Economic History, 58(1), pp.1-28.

Tobin, Jennifer L., and Susan Rose-Ackerman. 2011. 'When BITs have some bite: The politicaleconomic environment for bilateral investment treaties.' Review of International Organizations 6(1): 1-32.

Vernon, Raymond. 1971. Sovereignty at Bay: The Multinational Spread of US Enterprises. New York: Basic Books.

Waibel, Michael, Asha Kaushal, Kwo-Hwa Liz Chung, and Claire Balchin (eds). 2010. The Backlash against Investment Arbitration: Perceptions and Reality. Kluwer Law International.

Wellhausen, Rachel L. 2015. 'Bondholders vs. direct investors? Competing responses to expropriation.' International Studies Quarterly, 59(4): 750-764.

Wheeler, David. 2001. Racing to the bottom? Foreign investment and air pollution in developing countries. Journal of Environment and Development, 10(3): 225-245.

Williams, Zoe Philipps. 2016. Risky Business or Risky Politics: What Explains Investor-State Disputes? PhD. Hertie School of Governance.

Williamson, Jeffrey. 1993. Democracy and the "Washington consensus". World Development, 21(8): 1329-1336.

Williamson, Jeffrey. 2000. What should the World Bank think about the Washington Consensus?. World Bank Research Observer, 15(2): 251-264. 
Williamson, Oliver E. 1973. Markets and hierarchies: Some elementary considerations. American Economic Review, 63(2): 316-325.

Yackee, Jason Webb. 2009. 'Do BITs really work? Revisiting the empirical link between investment treaties and foreign direct investment.' In Karl Sauvant and Lisa Sachs (eds.), The Effect of Treaties on Foreign Direct Investment: Bilateral Investment Treaties, Double Taxation Treaties and Investment Flows. Oxford University Press.

Yeaple, Stephen Ross. 2003. The Role of Skill Endowments in the Structure of U.S. Outward Foreign Direct Investment. Review of Economics and Statistics, 85(3): 726-734. 